\title{
The Effect of Scientific Creativity in Inquiry Learning to Promote Critical Thinking Ability of Prospective Teachers
}

\author{
https://doi.org/10.3991/ijet.v14i14.9532 \\ Wahyudi, Ni Nyoman Sri Putu Verawati ${ }^{(凶)}$, Syahrial Ayub \\ Universitas Mataram, Mataram, Indonesia \\ veyra@unram.ac.id \\ Saiful Prayogi \\ Institut Keguruan dan Ilmu Pendidikan (IKIP), Mataram, Indonesia
}

\begin{abstract}
Teaching critical thinking (CT) to the prospective teacher has garnered attention for a while, and the teaching conduction to trained it is important to develop. This study aims to find out the effect of teaching implementation of scientific creativity in inquiry learning to promote the CT ability of prospective teachers. Scientific creativity in inquiry learning is apellation as the inquiry creative process (ICP) learning model. This study is a experimental research conducting with the randomized pretest-posttest control group design. Samples were chosen to be treated as experimental and control group. Two sample groups were prospective teacher of physic (PTP) in the faculty of teacher training and education (FKIP), Mataram University, Indonesia. The data of CT ability collected by instrument refer to Ennis-Weir Critical Thinking Essay Test. The data analysis descriptively and statistically were done to process the data of research result. Generally, the results shown that ICP learning model had a significant effect on the improvement of CT ability of prospective teacher of physic. The description of the research findings are described in this article.
\end{abstract}

Keywords-Scientific creativity, inquiry creative process, critical thinking ability

\section{Introduction}

One of the essential skills that the learners must have in the 21 st century is critical thinking (CT) skill [1]. In some countries, CT has become a major focus and competency in learning at all levels of their education [2]. In Indonesia, CT has also become a very important part of the competence to be achieved at the higher education level, as set forth in the Regulation of the Minister of Research, Technology and Higher Education of the Republic of Indonesia. Global Citizenship Education (GCE) recommends that universities should seek to facilitate students to analyze issues critically, identify creative and innovative solutions. A function of higher 
education is to teach students to think. University accreditation boards in some advanced countries, for example, the National Association of Industrial Technology (NAIT), the Accreditation Board of Engineering and Technology (ABET), and the International Technology Education Association (ITEA) recognize competencies such as CT, problem solving, communication, and teamwork in their accreditation criteria [3].

Fostering the development of students' critical thinking is regarded as an essential outcome of higher education [4], and in some countries has become a very important part as the main goal of learning and education [5]. Teaching critical thinking to the prospective teacher has garnered attention for a while, and the role of future teachers seems more crucial than ever before for educational systems in terms of seeking improvement in critical thinking [6]. In the faculty of education and teachers training, teacher educators have to teach and give cognitive skills to prospective teacher before they train them to the students in the classroom [7], and education before becoming a teacher is proper time to intervention activities which promote their critical thinking [8].

Educators have long been aware of the importance of CT skills as an outcome of student learning. However, teaching CT remains confusing for many instructors [9]. This is partly due to the lack of clarity the wide range of methods proposed to best teach of CT [9, 10]. Mitrevski and Zajkov [11] show that the trend of educators in branch countries identified using eighteen models and methods ranging from discussions, demonstrations, project work, to outdoor leasson methods, but there are not explicitly purposed to improve and train critical thinking skills. At higher education level, Bissell and Lemons [12] ascertained faculties who teach at universities consider CT a primary objective. It is a sad truth that the average college student does not think critically, and not all courses include critical thinking. Thompson [13] argued that in learning CT requires a holistic approach and should involve a set of appropriate learning models. Therefore, it is necessary to develop a set of specific learning models to promote learner CT skills. Some previous researchers recommended inquiry as a basis of learning models to promote students' critical thinking skills, because inquiry is a learning model for the purpose of teaching to think [14]. The aim of this study was to find out the effect of scientific creativity in inquiry learning to promote critical thinking ability of prospective teachers.

\section{$2 \quad$ Literature Review}

$\mathrm{CT}$ is reflective and reasonable thinking that is focused on deciding what to believe or do [15], its purposeful, self-regulatory judgment which results in interpretation, analysis, evaluation, and inference, as well as explanation of the evidential, conceptual, methodological, criteriological, or conceptual considerations upon which that judgment is based [16]. CT is a propensity and skill to engage in an activity with reflective skepticism [17]. It's used to pass judgment on any information, explain the reasons, and able to solve the problem of the unknown [18], so that each of individuals are able to understand any information or content on a particular thing 
[19]. CT is often called independent thinking, reflective thinking, or evaluative thinking, and it's the best understood as the ability of thinkers to take charge of their own thinking [20]. Despite differences among of thought and their approaches to defining critical thinking, there exist areas for agreement. The researchers of CT typically agree on the specific abilities encompassed by the definition, which include: analyzing arguments, claims, or evidence; making inferences using inductive or deductive reasoning; judging or evaluating; and decision making.

Stimulation of creative processes and $\mathrm{CT}$ in the context of education and learning are important. The integration of creative and $\mathrm{CT}$ has been emphasized in literature in recent decade [21,22] and the importance of combining these two thought processes to solve the problems [23]. Correlation of both is clear, that problem solving involves stages of generating ideas using creative processes and critical thinking [24]. CT can be considered as a multidimensional cognitive construct, as a result of the creative processes [25]. Halpern [26] conceptualizes critical and creative thinking as complementary, yet not identical processes, claiming that they may vary according to the strategies that are used to develop these skills through instructional programs.

Learning models based on inquiry activities have been widely developed for the purpose to promote learner CT skills [27], since inquiry is an instructional model that aims to guide about how learners think [14]. The processes of scientific creativity in the inquiry activities need to be revealed as a way to promote CT skills of physics prospective teachers. The development of learning models by integrating creativity processes with scientific inquiry activities needs to be explored and developed for that purpose. Creative processes (scientific creativity) potentially train the critical thinking ability of learners [28]. Aspects of scientific creativity are in the form of problem finding, problem solving, creating hypotheses, design experiment, and product design $[29,30,31,32,33]$. These aspects will later be integrated with the inquiry model into a set of learning model. In its development process as a learning model, scientific creativity in inquiry learning is apellation as inquiry creative process (ICP) learning model. The hypothetical framework of ICP learning model presented in Table 1. 
Table 1. The hypothetical framework of ICP learning model

\begin{tabular}{|l|l|}
\hline \multicolumn{1}{|c|}{ Learning phases } & \multicolumn{1}{c|}{ Learning activities } \\
\hline $\begin{array}{l}\text { Preparation and identification of the } \\
\text { problems }\end{array}$ & $\begin{array}{l}\text { Preparation and presentation of learning objectives } \\
\text { Learner find as many issues as they relate to learning materials } \\
\text { Learner choose one core problem to be tested } \\
\text { Learner formulate the problem to be tested }\end{array}$ \\
\hline $\begin{array}{l}\text { Creating and formulating the } \\
\text { hyphotheses }\end{array}$ & $\begin{array}{l}\text { Learner formulate hypotheses according to the selected problem } \\
\text { Learner re-examine the relevance of the hypothesis with the } \\
\text { formulation of problems that has been prepared }\end{array}$ \\
\hline Creatively experiment designing & $\begin{array}{l}\text { Learner identify and define operationally the variables in the } \\
\text { hypothesis to be tested } \\
\text { Learner prepare steps of hypothesis testing in the form of creative } \\
\text { experimental procedures. }\end{array}$ \\
\hline Science creatively problem solving & $\begin{array}{l}\text { Learner implementing the experimental steps that have been } \\
\text { prepared. } \\
\text { Learner checking the accuracy of the implementation of the } \\
\text { experimental steps they have undertaken. } \\
\text { Evaluate experimental results based on previously formulated } \\
\text { hypotheses. } \\
\text { Learner conclude the experimental results. }\end{array}$ \\
\hline Creatively product design & $\begin{array}{l}\text { Learner make an experimental resume that includes detailed } \\
\text { explanations with concept support from relevant sources. }\end{array}$ \\
\hline
\end{tabular}

\section{$3 \quad$ Methodology}

This study is an experimental research conducting with the randomized pretestposttest control group design [34]. Samples were chosen to be treated as experimental group (ICP learning model) and control group (conventional model). Sample randomization was done based on existing population. Two sample group in this study were prospective teachers of physic (PTP) in the faculty of teacher training and education (FKIP), Mataram University, Indonesia. The sample for the experimental and control group was conducted with $42(\mathrm{n}=42)$ participant, $21(\mathrm{n}=21)$ PTP were assigned to the experimental group, while $21(\mathrm{n}=21)$ were in the control group. Pretest and posttest were given to the both groups of samples the results were analyzed.

Data of CT ability collected by instrument of critical thinking essay test refers to four indicator of critical thinking ability that is measured, that are analysis, evaluation, inference, and decision making. Data analysis of was analyzed descriptively using multilevel scale (five scales) referring to Ennis-Weir Critical Thinking Essay Test (EWCTET) scoring technique where highest score of +3 and lowest -1 . The categorization of critical thinking ability was done with five criteria from not critically to very critically [35]. Increased students' critical thinking scores were analyzed using the $\mathrm{N}$-Gain equation.

Statistical data analysis was also performed in this study, the data analysis uses one-way-anova preceded by normality and homogeneity test of sample. All statistical data analysis using the Statistical Package for Social Science (SPSS) 23.0 software tool. 


\section{$4 \quad$ Results and Discussion}

Descriptively, the test result of prospective teachers' critical thinking testability can be seen through the Table 2 below.

Table 2. Critical thinking test result

\begin{tabular}{|l|c|c|c|c|c|c|c|}
\hline \multirow{2}{*}{ Sample group } & \multirow{2}{*}{$\mathbf{N}$} & \multicolumn{9}{|c|}{ Critical thinking score (CTs) \& criteria } & \multirow{2}{*}{ n-gain } & \multirow{2}{*}{ Criteria } \\
\cline { 3 - 6 } & & Pretest & \multicolumn{1}{|c}{ Criteria } & Posttest & \multicolumn{1}{c|}{ Criteria } & & High \\
\hline Experiment & 21 & 0,52 & Less critically & 17,48 & Critically & 0,72 & Less \\
\hline Control & 21 & 0,57 & Less critically & 3,85 & 0,13 & Low \\
\hline
\end{tabular}

Obviously, it was found that the mean score gained by the participants of experimental group on critical thinking ability test at the pretest is 0,52 which is then classified into "less critically" (less critically, if: $-1,6<\mathrm{CTs} \leq 4,8$ ), and the mean score gained at the posttest is 17,48 which is classified into "critically" (critically, if: $11,20<\mathrm{CTs} \leq 17,60)$ it was happened after having some treatments on ICP learning model, in which the n-gain is 0,72 that is categorized into "high" category. Conversely, the mean score gained by the participants of CT ability test on control group at the pretest is 0,57 which is classified into "less critically" and the mean score on the posttest is 3,85 which is categorized into "less critically," with n-gain at the 0,13 with the "low" criteria.

The statistical analysis was conducted to find out the effect of ICP learning model on improving the prospective teachers' CT ability. The hypothesis of the study states that there is a significant effect of using ICP learning model on impoving the prospective teachers' CT ability. The data were obtained from the results of pretest and postest of prospective teachers CT ability. The data were analyzed by the SPSS for windows version 23.0. The analysis was preceded by normality test using OneSample Kolmogorov-Smirnov Test and homogeneity test using Levene's Test of Equality of Variances. The summary of the result of normality and homogeneity test are provided in Table 3 .

Table 3. The summary of the result of normality and homogeneity test

\begin{tabular}{|l|c|c|c|c|}
\hline \multirow{2}{*}{\multicolumn{1}{|c|}{ Group of data }} & \multicolumn{2}{c|}{ Kolmogorov-Smirnov } & \multicolumn{2}{c|}{ Levene's Test } \\
\cline { 2 - 5 } & $\boldsymbol{N}$ & Sig. & Levene's test score & Sig. \\
\hline Pretest of CT ability & 42 & 0,200 & 0,000 & 0,992 \\
\hline Posttest of CT ability & 42 & 0,200 & 0,970 & 0,331 \\
\hline
\end{tabular}

Based on Table 3, it can be stated that the data were normally distributed and all the variances were homogeneous (sig normality and homogeneity $>0.05$ ). The comparation between the result of prospective teachers' CT ability on experimental group and those gained by the control group were found by analyzing the differences scores gained by the two groups on one-way anova analysis, the brief result of oneway anova analysis are provided on the Table 4 . 
Table 4. The results of one-way anova analysis

\begin{tabular}{|l|c|c|c|c|c|}
\hline \multicolumn{1}{|c|}{ Group } & Sum of squares & Df & Mean square & F & Sig. \\
\cline { 1 - 4 } Between Groups & 1947,524 & 1 & 1947,524 & \multirow{2}{*}{619,198} & 0,000 \\
\cline { 1 - 4 } Within Groups & 125,810 & 40 & 3,145 & & \\
\cline { 1 - 4 } Total & 2073,333 & 41 & & & \\
\hline
\end{tabular}

The result of one-way anova analysis shows that the significance of testing $(0.000)$ is less than the result of alfa testing $(<0,05)$, which then concluded that there is a significant different between prospective teachers' CT ability at the experimental group and the control group which is then lead the research conclusion into saying that there is significant effect of ICP learning model in improving the prospective teachers' CT ability. Thus, the alternative hypothesis of the study is accepted.

The implementation of ICP learning model to the prospective teachers of physics is in line with the demand that a physics learning has to master CT ability into it to correlate and interrelate between two or more theories and concepts in learning physics. The use of ICP learning model obviously increased the PTP ability in developing their critical thinking. The research finding of the research shows that through ICP learning model, the PTP enhance their critical thinking. Those enhancements were mostly enhanced from "less critically" category increased into "critically" category. The result of this current study is parallel with the previous relevant study which found that the intervention of scientific creativity to develop CT ability is significantly effective [36], in line with the result of this study, the implementation of exploration an creative ideas in the acquisition inquiry activity is highly enhance prospective teachers ability in developing their critical thinking [35].

The enhancement of prospective teacher's critical thinking ability through ICP learning model cannot be separated from the intervention of each phases implemented during the learning process in ICP model in which the phases of learning were consistently training the critical thinking ability of prospective teacher. The problem finding and science creatively problem solving which are the dimension of scientific creativity, both have a correlation in the context to train critical thinking. The cognitive dimensions of creative thinking certainly correlations with some of the dimensions of critical thinking, this is especially obvious when the students are thinking in the context of problem solving. When the students are thinking in a given context (critical thinking), they make use of various thinking processes (creative thinking). The properties of critical thinking are linked to the creative abilities during problem finding and problem solving [37]. Creative problem finding ability is defined as a kind of intellectual trait or ability that is demonstrated in the process of producing and expressing new-found questions in a unique, novel and useful and purposeful way, using existing contexts and experience. It is embodied not only in the quantity, but also in the diversification (types) and in the originality of the problems found [38].

Creating hypotheses is one of important parts in developing scientific creativity [39]. When problems are facing, hypothesis are needed to define the most appropriate way solving those problems [14], those will automatically reinforce to think critically [40]. Creatively product design is a part of scientific creativity in which the learners are demanded to be able to design scientific product as the result of scientific 
creativity [33], those points are the important invention in terms of developing prospective teachers CT ability.

The findings of this research answered the main facing problems in the teaching and learning of science, it was found that teaching science is not the matter of transferring knowledge only, furthermore, it is also about keeping the learner to be more creative and having a critical thinking in every single activity involves in the teaching and learning of science in the classroom practice, particularly at the physics subject at whole level of education [41]. Through ICP learning model, learning was prepared in such a way as into free space for innovative teaching and to promote inquiry and problem-solving strategies, leading students to achieve and show knowledge at the higher cognitive levels such as critical thinking ability. Moreover, ICP learning model also provide a process in which the learners are demanded to have a critical thinking. For this reason, students who have undergone some critical thinking lessons can produce a greater number of possible solutions to problems than those who have not had any training [42]. The ICP learning model uses a systematic and well-organized learning activity through some experimental activities which involves scientific creativity and science process skills in it. Science process skill has a great effect in learning because it helps learner to improve higher mental skill, such as critical thinking, decision making, and problem solving [43, 44]. Science process skill can be instrument that can improve critical thinking ability. For the sake of a broader teaching and learning results, it is important to teach some steps to reach and conquer the knowledge itself [45], in which it is definitely need whey the students conducting a scientific experiment during the learning process [46, 47].

\section{Conclusion}

After all, it can be inferred that there is some improvements on critical thinking ability of prospective teachers in which there were some significant different found between pre-condition where most of them were classified into "less critically" and post-condition where the prospective teachers are dominantly categorized into "critically" as the effect of ICP learning model. The finding says that the ICP learning model deserves to use as the alternative learning model, mainly if the teacher or lecturer want to promote critical thinking ability of prospective teachers.

\section{$6 \quad$ References}

[1] Prayogi S, Yuanita L \& Wasis. (2018). Critical Inquiry Based Learning: Model of Learning to Promote Critical Thinking Ability of Pre-service Teachers. J. Phys.: Conf. Ser. 947 1-6 https://doi.org/10.1088/1742-6596/947/1/012013

[2] Schmaltz R M, Jansen E, \& Wenckowski N. (2017). Redefining Critical Thinking: Teaching Students to Think like Scientists. Front. in Psych 8(459) 1-4 https://doi.org/10.3389/fpsyg.2017.00459

[3] Scott, S. (2008). Perceptions of Students' Learning Critical Thinking through Debate in a Technology Classroom: A Case Study. Jour. of Tech. Stud 34(1) 39-44 
[4] Tiruneh, D.T., DeCock, M., Weldeslassie, A.G., Elen, J. \& Janssen, R. (2017). Measuring Critical Thinking in Physics: Development and Validation of a Critical Thinking Test in Electricity and Magnetism. International Journal of Science and Mathematic Education, 15, 663-682 https://doi.org/10.1007/s10763-016-9723-0

[5] Weltzer-Ward, L.M. \& Carmona, G. (2008). Support of the critical thinking process in synchronous online collaborative discussion through model-eliciting activities. International Journal of Emerging Technologies in Learning, 3(3), 86-88. https://doi.org/10.3991/ijet.v3i1.677

[6] Sendag S., Erol O., Sezgin S., \& Dulkadir N. (2015). Preservice Teachers' Critical Thinking Dispositions and Web 2.0 Competencies. Contemporary Educational Technology, 6(3), 172-187.

[7] Ashton P. (1988). Teaching Higher-order Thinking and Content: An Essential Ingredient in Teacher Preparation. Gainesville: University of Florida Press.

[8] Warburton E. C. (2008). Changes in Dance Teachers' Beliefs About Critical Thinking Activities. Journal of Education and Human Development, 2(1), 1-16.

[9] Bensley, D.A., \& Murtagh, M.P. (2012). Guidelines for a scientific approach to critical thinking assessment. Teaching Psychology, 39, 5-16 https://doi.org/10.1177/00 98628311430642

[10] Abrami, P.C., Bernard, R.M., Borokhovski, E., Wade, A., Surkes, M.A., Tamim, R., \& Zhang, D. (2008). Instructional interventions affecting critical thinking skills and dispositions: A stage 1 meta-analysis. Review of Educational Research, 78(4), 1102-1134. https://doi.org/10.3102/0034654308326084

[11] Mitrevski, B. \& Zajkov, O. (2011). Mathematics and Science Teachers' Concept of Critical Thinking. Bulgaria Journal of Physics, 38, 318-324.

[12] Bissell, A.N. \& Lemons, P.P. (2006). A new method for assessing critical thinking in the classroom. BioScience, 56(1), 66-72. https://doi.org/10.1641/00063568(2006)056[0066:anmfac]2.0.co;2

[13] Thompson, C. (2011). Critical Thinking Across the Curriculum: Process Over Output. International Journal of Humanities and Social Science, 1(9), 1-7.

[14] Arends, R. (2012). Learning to Teach. Ninth Edition. New York: McGraw-Hill.

[15] Ennis, R.H. (1989). Critical Thinking and Subject Specificity: Clarification and Needed Research. Educational Researcher, 18(3), 4-10. https://doi.org/10.3102/0013 189x018003004

[16] Facione, P.A. (1990). Critical thinking: A Statement of Expert Consensus for Purposes of Educational Assessment and Instruction. Research Findings and Recommendations. Retrieved from ERIC database. (ED315 423).

[17] McPeck, J. (1990). Teaching Critical Thinking: Dialogue \& Dialectic. New York: Routledge.

[18] Thomas T. (2011). Developing First Year Students' Critical Thinking Skills. Asian Social Science, 7(4): 26-35.

[19] Zane T. (2013). Implementing Critical Thinking with Signature Assignments. Salt Lake Community College, Spring.

[20] Fahim, M. \& Masouleh, N.S. (2012). Critical Thinking in Higher Education: A Pedagogical Look. Theory and Practice in Language Studies, 2(7), 1370-1375. https://doi.org/10.4304/tpls.2.7.1370-1375

[21] Glassner, A., \& Schwartz, B. (2007). What stands and develops between creative and criatical thinking? Argumentation. Thinking Skills and Creativity, 2(1), 10-18. https://doi.org/10.1016/j.tsc.2006.10.001

[22] Padget, S. (2013). Creativity and Critical Thinking. New York: Routledge.

[23] Mumford, M. D., Hester, K. S., Robledo, I., Peterson, D. R., Day, E. A., Hougen, D. F., et al. (2012). Mental models and creative problem solving: The relationships of objective and subjective model attributes. Creativity Research Journal, 24(4), 311-330. https://doi.org/10.1080/10400419.2012.730008

[24] Grohman, M., Wodniecka, Z., \& Klusak, M. (2006). Divergent thinking and evaluation skills: Do they always go together? Journal of Creative Behavior, 40(2), 125-145. https://doi.org/10.1002/j.2162-6057.2006.tb01269.x

[25] Philley, J. (2005). Critical Thinking Concepts. Professional Safety, 50, 26-32. 
[26] Halpern, D.F. (1998). Teaching Critical Thinking for Transfer Across Domains. American Psychologist, 53(4), 449-455. https://doi.org/10.1037//0003-066x.53.4.449

[27] Kazempour, E. (2013). The Effects of Inquiry-Based Teaching on Critical Thinking of Students. Journal of Social Issues \& Humanities, 1(3), 23-27.

[28] Adams, K. (2006). The Sources of Innovation and Creativity. National Center on Education and Economy. USA.

[29] Türkmen, H. \& Sertkahya, M. (2015). Creative Thinking Skills Analysis of Vocational High School Students. Journal of Educational and Instructional Studies in the World, 5(1), 74-84.

[30] Ayas, B. \& Sak, U. (2014). Objective Measure of Scientific Creativity: Psychometric Validity of the Creative Scientific Ability Test. Elsevier: Thinking Skills and Creativity, 13, 195-205. https://doi.org/10.1016/j.tsc.2014.06.001

[31] Hu, W., Shi, Q.Z., Han, Q., Wang, X. \& Adey, P. (2010). Creative Scientific Problem Finding and Its Developmental Trend. Creativity Research Journal, 22(1), 1-7. https://doi.org/10.1080/10400410903579551

[32] Aktamis, H. \& Ergin, O. (2008). The Effect of Scientific Proccess Skill Education on Student's Scientific Creativity, Science Attitudes, And Academic Achivements. AsiaFacific Forum on Science Learning and Teaching, 9, 1-21.

[33] Hu, W. \& Adey, P. (2010). A Scientific Creativity Test for Secondary School Students. International Journal for Science Education, 24(4), 389-403. https://doi.org/10.1080/09 500690110098912

[34] Fraenkel, J.R., Wallen, N.E., \& Hyun, H.H. (2012). How to Design and Evaluate Research in Education (8th ed.). New York: McGraw-Hill.

[35] Prayogi, S., Yuanita, L. \& Wasis. (2018). Critical Inquiry Based Learning: A Model of Learning to Promote Critical Thinking Among Prospective Teachers of Physic. Journal of Turkish Science Education, 15(1), 43-56. https://doi.org/10.1088/1742-6596/947/1/012013

[36] Koray, Ö. \& Köksal, M.S. (2009). The effect of creative and critical thinking-based laboratory applications on creative and logical thinking abilities of prospective teachers. Asia-Pacific Forum on Science Learning and Teaching, 10(1), 1-13.

[37] Kousoulas, F., \& Mega, G. (2008). Creative and critical thinking in the context of problem finding and problem solving: A research among students in primary school. Retrieved from http://www.ep.liu.se/ecp/021/vol1/011/ecp2107011.pdf

[38] Han, Q., Hu, W., Liu, J., Jia, X. \& Adey, P. (2013). The Influence of Peer Interaction on Students' Creative Problem-Finding Ability. Creativity Research Journal, 25(3), 248-258. https://doi.org/10.1080/10400419.2013.813754

[39] Jiang, M. \& Thagard, P. (2014). Creative Cognition in Social Innovation. Creativity Research Journal, 26(4), 375-388. https://doi.org/10.1080/10400419.2014.961774

[40] Alberta Education. (2010). Inspiring Education: A Dialogue with Albertans. Edmonton, AB: Alberta Education.

[41] Šorgo, A. (2012). Scientific Creativity: The Missing Ingredient in Slovenian Science Education. European Journal of Educational Research, 1(2), 127-141. https://doi.org/10.12973/eu-jer.1.2.127

[42] de Bono, E. (1976). Teaching thinking. London: Penguin

[43] Lee, A.T., Hairston, R.V., Thames, R., Lawrence, T. \& Herron, S.S. (2002). Using a computer simulation to teach science process skills to college biology and elementary education majors. Computer Simulations Bioscene, 28(4), 35- 42.

[44] Koray, Ö., Köksal, M. S., Özdemir, M., \& Presley, A. I. (2007). The effect of creative and critical thinking-based laboratory applications on academic achievement and science process skills. Elementary Education Online, 6(3), 377-389.

[45] Karsli, F. \& Şahin, Ç. (2009). Developing worksheet based on science process skills: Factors affecting solubility. Asia-Pacific Forum on Science Learning and Teaching, 10(1), $1-12$.

[46] Harlen, W. (1999). Purposes and procedures for assessing science process skills. Assessment in Education, 6(1), 129-144.

[47] Taconis, R., Ferguson-Hessler, M.G.M \& Broekkamp, H. (2000). Teaching Science Problem Solving: An Overview of Experimental Work. Journal of Research in Science Teaching, 38, 442-468. https://doi.org/10.1002/tea.1013 


\section{$7 \quad$ Authors}

Wahyudi is a lecturer in Electronics courses, majoring in Physics Education, Faculty of Teaching and Education, Universitas Mataram, Indonesia.

Ni Nyoman Sri Putu Verawati is a lecturer in Fundamental Physics course, majoring in Physics Education, Faculty of Teaching and Education, Universitas Mataram, Indonesia.

Syahrial Ayub is a lecturer in Thermodinamic course, majoring in Physics Education, Faculty of Teaching and Education, Universitas Mataram, Indonesia.

Saiful Prayogi is lecturer in Physics Education, faculty of Mathematics and Science Education, and member of Central Study of Science and Mathematics education, Institut Keguruan dan Ilmu Pendidikan (IKIP) Mataram, Indonesia.

Article submitted 2018-09-12. Resubmitted 2019-03-27. Final acceptance 2019-04-04. Final version published as submitted by the authors. 